vitro cho nhau ở mức rất cao. Dựa trên biểu đồ 3.2 và 3.3 , ta cũng có thể thây được MIC colistin giảm xuống rõ rệt khi phối hợp với Mi (Do). Nếu xét nồng độ $\leq 8 \mathrm{mg} / \mathrm{L}$, kết quả nghiên cứu cho thấy làm giảm MIC của Co thì Mi làm giảm nhiều hơn so với Do và nồng độ này có ý nghĩa lâm sàng. Vậy với kết quả trên ta có thể tham khảo in vitro để phối hợp Co với Mi và Co với Do để giảm nồng độ của Co xuống, giảm tác dụng phụ trên bệnh nhân cũng như hạn chế kháng thuốc.

So sánh với nghiên cứu khác cũng cho kết quả cao như tác giả Yang YS, et al. khi phối hợp Co với Mi làm gia tăng hiệu quả cho nhau (hiệp đồng hoặc cộng) là 92\% [6]. Tương tự với Co với Do là $70 \%$ của tác giả Miyasaki $Y$, et al. [3].

Bên cạnh đó bảng 3.2 cũng cho ta thấy sự mặt của Co $\leq 2 \mathrm{mg} / \mathrm{L}$ cũng giảm MIC của Mi từ $\mathrm{R}$ chuyển thành I, S với tỷ lệ cao $96.4 \%$. Còn với Do là $35.5 \%$. Ta thây MIC50 và MIC90 của Mi thấp hơn nhiều so với Do (bảng 3.1) nên sau khi phối hợp với $\mathrm{Co} \leq 2 \mathrm{mg} / \mathrm{L}$ cũng chuyển $\mathrm{R}$ sang $\mathrm{S}$, I của Mi cao hơn so với Do. Do đó trên lâm sàng phối hợp kháng sinh nên dựa vào MIC của kháng sinh phối hợp để mang lại hiệu quả cao, gia tăng diệt khuẩn, hạn chế kháng thuốc.

\section{KẾT LUÂN}

Sự phối hợp colistin với minocycline và colistin với doxycycline cho thấy làm gia tăng hiệu quả in vitro cho nhau với tỷ lệ cao trên chủng MDR A. baumannii. Với tình trạng MDR $A$. baumannii ngày càng gia tăng như hiện nay, sự phối hợp kháng sinh này giúp tối ưu hóa liều lượng colistin giảm tác dụng phụ trên bệnh nhân. Đồng thời phối hợp này còn giúp giảm MIC của kháng sinh phối hợp với colistin giúp gia tăng khả năng diệt khuẩn, hạn chế tình trạng kháng thuốc.

\section{TÀI LIẸU THAM KHẢO}

1. Hà ĐTT. Phân tích tình hình sử dung kháng sinh trong điều trị nhiểm khuẩn Gram âm đa kháng tai Bệnh viện đa khoa Đông Nai. Tạp chí y học Việt Nam. 2021;501(2):179.

2. Lima WG, Brito JCM, et al. Rate of polymyxin resistance among Acinetobacter baumannii recovered from hospitalized patients: a systematic review and meta-analysis. European journal of clinical microbiology \& infectious diseases : official publication of the European Society of Clinical Microbiology. 2020;39(8):1427-38.

3. Miyasaki $\mathbf{Y}$, Morgan MA, et al. In vitro activity of antibiotic combinations against multidrug-resistant strains of Acinetobacter baumannii and the effects of their antibiotic resistance determinants. FEMS Microbiol Lett. 2012;328(1):26-31.

4. Nation RL, Li J. Colistin in the 21st century. Current opinion in infectious diseases. 2009;22(6):535.

5. White RL, Burgess DS, et al. Comparison of three different in vitro methods of detecting synergy: time-kill, checkerboard, and E-test. Antimicrobial agents and chemotherapy. 1996;40(8):1914-8.

6. Yang YS, Lee $Y$, et al. In Vivo and In Vitro Efficacy of Minocycline-Based Combination Therapy for Minocycline-Resistant Acinetobacter baumannii. Antimicrobial agents and chemotherapy. 2016;60(7):4047-54.

7. CLSI. Performance Standards for Antimicrobial Susceptibility Testing. Clinical and Laboratory Standards Institute. 2021;CLSI supplement M100(31st ed).

\title{
ĐÁNH GIÁ KẾT QUẢ AFATINIB ĐÎ̀̂U TRI UNG THƯ PHỔI KHÔNG TẾ BÀO NHỎ GIAI ĐOẠN IIIB-IV Có ĐộT BIỀN EGFR
}

\section{TÓM TẮT}

Mục tiêu: Đánh giá kết quả điều trị ung thư phổi không tế bào nhỏ giai đoan IIIB-IV bằng Afatinib tại Bệnh viện Bạch Mai. Đối tượng và phương pháp nghiên cứu: 59 bệnh nhân ung thư phổi không tế bào nhỏ có đột biến EGFR giai đoạn tiến xa và di căn được điều trị bằng thuốc Afatinib tại Trung tâm $Y$ học hạt nhân và Ung bướu, bệnh viện Bạch Mai từ tháng

${ }^{1}$ Trung tâm Y học hạt nhân và Ung bướu, Bệnh viện Bach Mai

Chịu trách nhiệm chính: Võ Thị Huyền Trang

Email: bsubvohuyentrang@gmail.com

Ngày nhân bài: 9.8.2021

Ngày phản biên khoa hoc: 4.10 .2021

Ngày duyệt bài: 14.10.2021

\section{Võ Thị Huyền Trang1, Phạm Cẩm Phương ${ }^{1}$} 1/2019 đến tháng 4/2021. Kết quả nghiên cứu: $76,2 \%$ bênh nhân đat đáp ứng toàn bô, $13,6 \%$ bênh nhân ổn định bệnh; tỷ lệ kiểm soát bệnh đạt $89,8 \%$. Tỷ lệ đáp ứng từng loại tổn thương như sau: $U$ phổi nguyên phát $(68,5 \%)$; di căn phổi đối bên $(65,3 \%)$; di căn thân kinh trung ương $(80 \%)$; di căn thượng thận $(66,7 \%)$; di căn gan $(71,4 \%)$. Tỳ lệ đáp ứng ở nhóm bệnh nhân có đột biến gen EGFR thường gặp đạt $70,3 \%$ và ở nhóm hiếm gặp đạt $66,7 \%$. Tác dụng không mong muốn thường gặp nhất là tiêu chảy $(88,9 \%)$ và ban mụn trên da $(87,1 \%)$ chủ yếu ở độ 1 và độ 2 . Không có bệnh nhân nào tử vong do tác dụng phụ không mong muốn. Kết luận: Bệnh nhân ung thư phổi không tế bào nhỏ giai đợoạn IIIIB-IV có đột biến gen EGFR điều trị bằng Afatinib cho tỷ lệ đáp ứng cao, dung nạp tốt. 
Từ khóa: Ung thư phổi không tễ bào nhỏ, EGFR, Afatinib.

\section{SUMMARY}

EVALUATION OF RESULTS OF AFATINIB TREATMENT OF STAGE IIIB-IV NON-SMALL CELL LUNG CANCER WITH EGFR MUTATION

Objective: To evaluate the results Afatinib treatment in the stage IIIB-IV non-small cell lung cancer with Afatinib at Bach Mai Hospital. Patients and methods: 59 advanced and metastatic non-small cell lung cancer patients with EGFR mutations were treated with afatinib at the Nuclear Medicine and Oncology Center, Bach Mai Hospital from January 2019 to April 2021. Results: $76.2 \%$ of patients achieved a complete response, $13.6 \%$ of patients stabilized; disease control rate reached $89.8 \%$.The response rate for each type of lesion was as follows: Primary lung tumor (68.5\%); contralateral lung metastases $(65.3 \%)$; central nervous system metastasis ( $80 \%)$; adrenal metastases $(66.7 \%)$; liver metastases $(71.4 \%)$. The response rate in the group of patients with common EGFR mutations was $70.3 \%$ and in the rare group was $66.7 \%$. The most common adverse effects were diarrhea (88.9\%) and acne skin rash $(87.1 \%$ ) mainly in grade 1 and grade 2 . No patient died from unwanted side effects. Conclusions: Patients with stage IIIB-IV non-small cell lung cancer with EGFR gene mutations treated with Afatinib have a high response rate and good tolerability.

Keywords: Non Small Cell Lung Cancer, EGFR, Afatinib.

\section{I. ĐẶT VẤN ĐỀ}

Ung thư phổi là một trong những loại ung thư có tỷ lệ mắc mới và tỷ lệ tử vong cao nhất trên thế giới. Theo GLOBOCAN 2020[1], ước tính có khoảng 2.2 triêuu trường hợp mắc mới ung thư phổi, chiếm $11.4 \%$ tổng số các trường hợp mắc ung thư mới. Và mặc dù các phương pháp điều trị ngày càng phát triển thì tỳ lệ tử vong do ung thư vẫn rất cao, ngay cả ở những nước phát triển. Ước tính năm 2020, có khoảng 1.76 triệu trường hợp tử vong do ung thư phổi, chiếm tới $18.4 \%$ các trường hợp tử vong do ung thư nói chung. Tại Việt Nam, ung thư phổi đứng hàng thứ 2 sau ung thư gan, ước tính năm 2020 có hơn 23000 ca mắc mới, chiếm $14.4 \%$ và hơn 16 700 ca tử vong, chiếm $18.4 \%$ [1]. Những năm gần đây, với những tiến bộ mới trong nghiên cứu con đường dẫn truyển tín hiệu tế bào cũng như các đích phân tử nhất là các tác nhân ức chế Tyrosin kinase tác động lên yếu tố phát triển biểu bì EGFR (Epidermal Growth Factor Receptor) đã làm thay đổi đáng kể tiên lượng và thời gian sống bệnh không tiến triển của những bệnh nhân ung thư phổi giai đoạn muộn. Hơn nửa, tỷ lệ đột biến gen EGFR ở người châu Á chiếm tỷ lệ khá cao so với người châu Âu và châu Mỹ La tinh nên vai trò của các thuốc ức chế tyrosin kinase (TKIs) lại càng được khẳng định Afatinib là một trong những thuốc TKIs được chấp thuận trong điều trị ung thư phổi. Đây là thuốc TKIs thế hệ 2, được FDA Hoa Kỳ chấp thuận cho chỉ định điều trị ung thư phổi không tế bào nhỏ giai đoạn tiến xa di căn có đột biến gen EGFR từ tháng 7/2013. Chính vì thế, chúng tôi tiến hành đề tài này với mục tiêu: Đánh giá kêt quả điều trị ung thư phổi không tế bào nhỏ giai đoạn IIIB-IV có đôt biên gen EGFR bằng Afatinib tại Bênh viện Bạch Mai

\section{II. ĐỐI TƯỢNG VÀ PHƯƠNG PHÁP NGHIÊN CỨU}

Đối tượng nghiên cứu: Các bệnh nhân UTPKTBN có đột biến EGFR giai đoạn tiến xa và di căn được điều trị bằng thuốc Afatinib tại Trung tâm $Y$ học hạt nhân và Ung bướu, bệnh viện Bạch Mai từ tháng 1/2019 đến tháng 4/2021

\section{Tiêu chuânn lựa chơn bênh nhân}

- Bênh nhân được chẩn đoán UTPKTBN Ioại ung thư biểu mô tuyến, giai đoạn IIIB và giai đoạn IV (AJCC 2018).

- Có đột biến EGFR loại nhạy cảm với thuốc Afatinib.

- Được điều trị bước một bằng Afatinib 40mg, uống 01 viên/ngày trong thời gian ít nhất 03 tháng tính đến thời điểm kết thúc nghiên cứu.

- Đánh giá chỉ số toàn trạng trước điều trị (ECOG): 0, 1, 2.

- Tuổi $\geq 18$.

\section{Tiêu chuấn loai trừ}

- Không đáp ứng một trong các tiêu chuẩn lựa chọn.

- Có ung thư khác phối hợp đã được chẩn đoán xác định.

- Bệnh nhân không đồng ý tham gia nghiên cứu.

- Không có đây đủ thông tin trong hồ sơ bệnh án.

Phương pháp nghiên cứu: Nghiên cứu mô tả hồi cứu và tiến cứu quả.

Xử lý và phân tích số liệu: Sử dụng phần mềm SPSS version 20.0 cho các phân tích thống kê.

\section{KẾT QUẢ NGHIÊN CỨU}

\section{Đặc điểm tuổi bênhh nhân}

Bảng 1: Đặc điếm tuổi bệnh nhân

\begin{tabular}{|c|c|}
\hline Nhóm tuối $(\mathbf{n = 5 9 )}$ & Tỷ lệ $\%$ \\
\hline$\leq 50$ & 10,2 \\
\hline $51-70$ & 71,2 \\
\hline$>70$ & 18,6 \\
\hline Tống & $\mathbf{1 0 0}$ \\
\hline Tuối trung bình & $62,0 \pm 8,7$ \\
\hline
\end{tabular}

Nhận xét: Tuối thường gặp của nhóm bệnh nhân nghiên cứu là từ 51 đến 70 tuổi $(71,2 \%)$ 
Giới tính

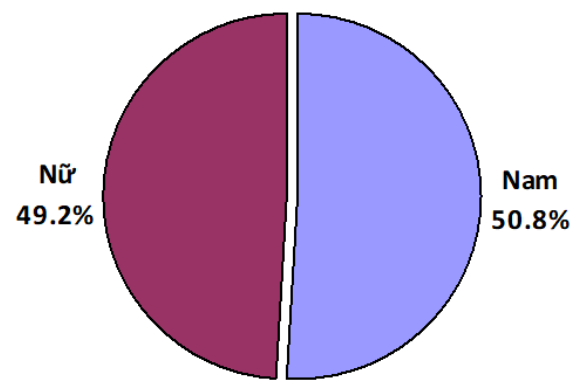

Biểu đồ 1. Đặc điểm giới tính của nhóm bệnh nhân $(p<0,001)$

Nhận xét: Tỷ lệ nam/ nữ trong nhóm bệnh nhân nghiên cứu là 1,03.

Chỉ số toàn trang

Bảng 2. Đặc điếm chỉ số toàn trạng

\begin{tabular}{|c|c|c|}
\hline $\begin{array}{c}\text { Chỉ số toàn } \\
\text { trạng }\end{array}$ & $\begin{array}{c}\text { Số bệnh } \\
\text { nhẩn }\end{array}$ & Tỷ lệ (\%) \\
\hline PS 0 & 21 & 35,5 \\
\hline PS 1 & 27 & 45,7 \\
\hline PS 2 & 11 & 18,8 \\
\hline Tống & $\mathbf{5 9}$ & $\mathbf{1 0 0}$ \\
\hline
\end{tabular}

Nhận xét: Đa số bệnh nhân trong nhóm nghiên cứu có chỉ số toàn trạng PS $0-1$, cụ thế PS 0 chiếm 35,5\%, PS 1 chiếm 45,7\%

\section{Lý do vào viênn}

\section{Bảng 3. Lý do vào viên}

\begin{tabular}{|c|c|c|}
\hline Triệu chứng & $\begin{array}{c}\text { Số beênh } \\
\text { nhân (n) }\end{array}$ & $\begin{array}{c}\text { Tỷ lệ } \\
\mathbf{( \% )}\end{array}$ \\
\hline Ho kéo dài & 10 & 16,9 \\
\hline Ho ra máu & 7 & 11,8 \\
\hline Đau ngực & 20 & 33,8 \\
\hline Khó thớ & 9 & 15,2 \\
\hline Gây sút cân & 7 & 11,8 \\
\hline Khác & 6 & 10,5 \\
\hline Tống & $\mathbf{5 9}$ & $\mathbf{1 0 0}$ \\
\hline
\end{tabular}

Nhận xét: Bệnh nhân vào viện với lý do đau ngực chiếm tỷ lệ cao nhất $33,8 \%$, tiếp đến là ho kéo dài chiếm $16,9 \%$, khó thở chiếm 15,2\%.

Đặc điểm khối u nguyên phát

Bảng 4. Đặc điểm về kích thước của khối u nguyên phát

\begin{tabular}{|c|c|c|c|c|}
\hline \multirow{5}{*}{$\begin{array}{l}\text { Xêp } \\
\text { loại } \\
\text { TT }\end{array}$} & \multicolumn{2}{|r|}{ Đặc điểm } & $\begin{array}{l}\text { Số bệnh } \\
\text { nhân (n) }\end{array}$ & $\begin{array}{c}\text { Tý lệ } \\
\text { \% }\end{array}$ \\
\hline & \multicolumn{2}{|r|}{$\mathrm{T} 1$} & 5 & 8,5 \\
\hline & \multicolumn{2}{|r|}{ T2 } & 15 & 25,4 \\
\hline & \multicolumn{2}{|r|}{ T3 } & 28 & 47,4 \\
\hline & \multicolumn{2}{|r|}{$\mathrm{T} 4$} & 11 & 18,7 \\
\hline \multirow{3}{*}{$\begin{array}{l}\text { Xâm } \\
\text { lấn }\end{array}$} & \multirow{3}{*}{ Có } & Trung thất & 11 & 18,6 \\
\hline & & Thành ngực & 9 & 15,2 \\
\hline & & Không & 39 & 66,2 \\
\hline
\end{tabular}

Nhận xét: Đa số u xếp loại T3, T4 cụ thế số bệnh nhân có $T 3$ là 28 chiếm tỷ lệ cao nhất với 47,4\%. Có 11 trường hợp bệnh nhân xâm lấn trung thất chiếm $18,6 \%$; u xẩm lấn thành ngực có 9 bệnh nhân chiếm 15,2\%.

Tình trạng di căn xa

Bảng 5. Vị trí di căn

\begin{tabular}{|c|c|c|}
\hline Vị trí di căn & $\begin{array}{c}\text { Số bệnh nhân có di } \\
\text { căn/ 59 bệnh nhân }\end{array}$ & $\begin{array}{c}\text { Tỷ lệ } \\
\mathbf{( \% )}\end{array}$ \\
\hline Màng phối & 12 & 20,3 \\
\hline Phối đô̂i bên & 21 & 35,6 \\
\hline Não & 12 & 20,3 \\
\hline Xương & 21 & 35,6 \\
\hline Thượng thận & 6 & 10,2 \\
\hline Gan & 7 & 11,9 \\
\hline
\end{tabular}

Nhân xét: Tỷ lệ di căn xương và di căn phố đối bên chiếm tỳ lế cao nhất là $35,6 \%$, tiếp đến là di căn màng phổi, di căn não chiếm 20,3\%, tỷ lệ di căn thượng thâan tỷ lệ thấp nhất chiếm 10,2\%.

\section{Xét nghiệm đột biển}

Bảng 6. Xét nghiệm đột biến gen

\begin{tabular}{|c|c|c|}
\hline Tình trạng đột biến EGFR & $\begin{array}{c}\text { Số bệnh } \\
\text { nhẩn } \\
(\mathbf{n})\end{array}$ & $\begin{array}{c}\text { Tỷ lề } \\
\mathbf{( \% )}\end{array}$ \\
\hline Đột biến xóa đoạn exon 19 & 25 & 42,4 \\
\hline Đọ̣t biến L858R trên exon 21 & 19 & 32,2 \\
\hline Đột biến G719X trên exon 18 & 4 & 6,8 \\
\hline Đột biến S768I trên exon 20 & 3 & 5,1 \\
\hline Đột biến L861Q trên Exon 21 & 3 & 5,1 \\
\hline Đột biến G719S trên exon 18 & 5 & 8,4 \\
\hline Tống & $\mathbf{5 9}$ & $\mathbf{1 0 0}$ \\
\hline
\end{tabular}

Nhân xét: Trong nhóm bệnh nhân nghiên cứu đột biến xóa đoạn trên exon 19 là phố biến nhất chiếm $42,4 \%$, tiếp đến là đột biến $L 858 R$ trên exon 21 chiếm 32,2\%. Còn lại là các đột biến hiếm găp.

\section{Xét nghiệm chất chỉ điểm khối u}

Bảng 7. Xét nghiệm chất chỉ điểm khôi u CEA

\begin{tabular}{|c|c|c|}
\hline Nông độ (ng/ml) & $\begin{array}{l}\text { Số bệnh } \\
\text { nhân (n) }\end{array}$ & $\begin{array}{l}\text { Tý lế } \\
(\%)\end{array}$ \\
\hline$\leq 5.00$ & 11 & 18,6 \\
\hline $5.01-20.00$ & 11 & 18,6 \\
\hline$>20$ & 37 & 62,7 \\
\hline Tống & 59 & 100 \\
\hline $\begin{array}{c}\text { Nồng độ CEA } \\
\text { trung binh }(\mathrm{ng} / \mathrm{ml})\end{array}$ & \multicolumn{2}{|c|}{$289,65 \pm 130,4$} \\
\hline
\end{tabular}

Nhânn xét: Tỷ lệ bệnh nhân có nồng độ CEA trên $20 \mathrm{ng} / \mathrm{ml}$ chiếm tỷ lệ cao nhất $62,7 \%$. Nồng độ CEA trung bình lúc chẩn đoán của nhóm bệnh nhân nghiên cứu là 289,65 $\pm 130,4$ (ng/ml)

\section{Kết quả điêu trì}

Bảng 8. Thời gian sử dung thuốc

\begin{tabular}{|c|c|c|c|}
\hline & $\begin{array}{c}\text { Trung } \\
\text { bình } \\
\text { (tháng) }\end{array}$ & $\begin{array}{c}\text { Min } \\
\text { (tháng) }\end{array}$ & $\begin{array}{c}\text { Max } \\
\text { (tháng) }\end{array}$ \\
\hline $\begin{array}{c}\text { Thời gian sứ } \\
\text { dụng thuốc (tháng) }\end{array}$ & $\begin{array}{c}12,4 \pm \\
6,1\end{array}$ & 3,83 & 27,7 \\
\hline
\end{tabular}

Nhân xét: Thời gian sử dụng thuốc trung bình của nhóm bệnh nhân nghiên cứu là 12,4 tháng, thời gian ngắn nhất là 3,83 tháng, dài 
nhất là 27,7 tháng.

\section{Đáp ứng chủ quan}

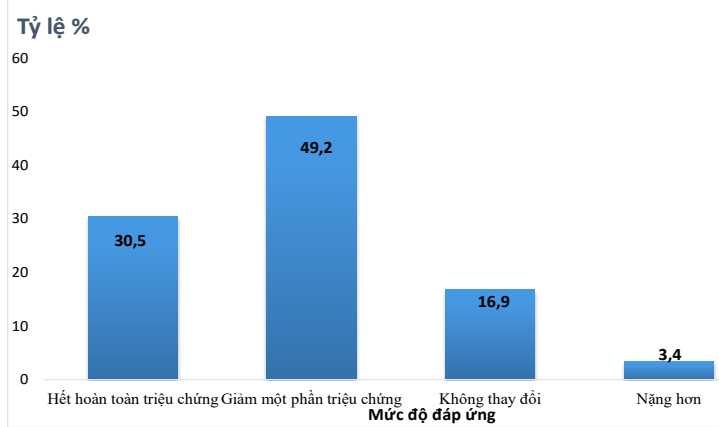

Biểu đồ 2. Tỷ lệ bệnh nhân theo mức độ đáp ứng điều trị chủ quan $(n=59)$

Nhân xét: Trong nhóm bênh nhân nghiên cứu có $49,2 \%$ bênh nhân có đáp ứng chủ quan một phần, 30,5\% bệnh nhân đáp ứng chủ quan hoàn toàn, $16,9 \%$ bệnh nhân có bệnh ổn định, và $3,4 \%$ bệnh nhân bệnh tiến triển.

\section{Đáp ứng khách quan}

Bảng 9. Đáp ứng khách quan

\begin{tabular}{|c|c|c|}
\hline Đáp ứng & $\begin{array}{c}\text { Số bệnh } \\
\text { nhân }(\mathbf{n})\end{array}$ & $\begin{array}{c}\text { Tỷ lệ } \\
\mathbf{( \% )}\end{array}$ \\
\hline Dáp ứng hoàn toàn & 12 & 20,3 \\
\hline Đáp ứng một phần & 33 & 55,9 \\
\hline Bệnh giữ nguyên & 8 & 13,6 \\
\hline Bệnh tiến triến & 6 & 10,2 \\
\hline Tống & 59 & 100 \\
\hline
\end{tabular}

Nhân xét: $76,2 \%$ bênh nhân đat đáp ứng chung, trong đó đáp ứng hoàn toàn $20,3 \%$, đáp ứng một phần $55,9 \%$.

Tỷ iệ kiểm soát bệnh

Đáp ứng liên quan tới tình trạng đột biến gen EGFR

Bảng 10. Đáp ứng theo tình trang đột biến gen EGFR

\begin{tabular}{|c|c|c|c|c|c|c|}
\hline \multirow{2}{*}{$\begin{array}{c}\text { Yêuu tố } \\
\text { liến quân lệ đáp ứng }\end{array}$} & \multicolumn{2}{|c|}{ Đáp ứng } & \multicolumn{2}{|c|}{ Không đáp ứng } & \multicolumn{2}{c|}{ Tống } \\
\cline { 2 - 7 } & $\mathbf{n}$ & $\mathbf{\%}$ & $\mathbf{n}$ & $\mathbf{\%}$ & $\mathbf{n}$ & $\mathbf{\%}$ \\
\hline Đột biến thường gặp & 35 & 79,5 & 9 & 20,5 & 44 & 100 \\
\hline Đột biến hiếm gặp & 10 & 66,7 & 5 & 33,3 & 15 & 100 \\
\hline Tống (N=59) & $\mathbf{4 5}$ & $\mathbf{7 6 , 2}$ & $\mathbf{1 4}$ & $\mathbf{2 3 , 8}$ & $\mathbf{5 9}$ & $\mathbf{1 0 0}$ \\
\hline
\end{tabular}

Nhận xét: Tỷ lê đáp ứng trên nhóm bệnh nhân có đột biến gen EGFR thường gặp là 79,5\% với 35/44 bệnh nhân có đáp ứng. Tỷ lệ đáp ứng trên nhóm bệnh nhân có đột biến gen EGFR hiếm gặp là 66,7\%, với 10/15 bệnh nhân có đáp ứng.

Đáp ứng liên quan tới nhóm đột biến EGFR thường gặp

Bảng 11. Tỷ lệ đáp ứng tại Exon 19 DEL và Exon 21 L858R

\begin{tabular}{|c|c|c|c|c|c|c|c|}
\hline \multirow{2}{*}{ Tỷ lệ đáp ứng } & \multicolumn{2}{|c|}{ Đáp ứng } & \multicolumn{2}{|c|}{ Không đáp ứng } & \multicolumn{2}{|c|}{ Tống } & \multirow{2}{*}{ p } \\
\cline { 2 - 7 } Yếu tồn quan & $\mathbf{n}$ & $\mathbf{\%}$ & $\mathbf{n}$ & $\mathbf{\%}$ & $\mathbf{n}$ & $\mathbf{\%}$ & \\
\hline Đột biến Exon 19 DEL & 22 & 88 & 3 & 22 & 25 & 100 & \\
\hline Dột biến Exon 21 L858R & 13 & 68,4 & 6 & 31,6 & 19 & 100 & \multirow{2}{*}{0,406} \\
\hline Tống (n=44) & $\mathbf{3 5}$ & $\mathbf{7 9 , 5}$ & $\mathbf{9}$ & $\mathbf{2 0 , 5}$ & $\mathbf{4 4}$ & $\mathbf{1 0 0}$ & \\
\hline
\end{tabular}

Nhân xét: Tỷ lệ đáp ứng tai vị trí đột biến Exon 19 DEL là $88 \%$ cao hơn tai Exon 21 L858R $(68,4 \%)$ là có sự khác biệt, tuy nhiên sự khác biệt này không có ý nghĩa thống kê với $p=0,406$. 
Tác dụng không mong muốn thường gặp

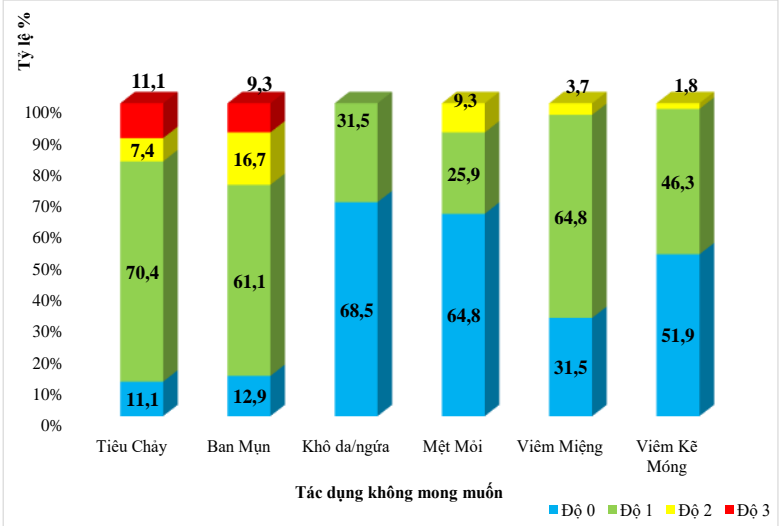

Biểu đồ 3.7. Tác dụng không mong muốn thường găp

Nhận xét: Tác dụng không mong muốn thường gặp nhất là tiêu chảy với $88,9 \%$ tiếp đến là ban da dạng mụn chiếm $87,1 \%$, viêm kẽ móng chiếm $46,3 \%$. Đa số các tác dụng phụ đều ở độ 1 , và độ 2.

\section{BÀN LUÂN}

Nghiên cứu của chúng tôi trên 59 bệnh nhân mắc ung thư phổi không tế bào nhỏ giai đoạn IIIB-IV có đột biến gen EGFR được điều trị bằng thuốc Afatinib. Tuổi trung bình của nhóm bệnh nhân nghiên cứu là 62 tuổi, và nhóm tuổi chiếm tỷ lệ cao nhất là nhóm từ 51 đến 70 tuổi, chiếm tỷ lệ $71,2 \%$. Tỷ lệ nữ là $49,2 \%$ nam là $50,8 \%$. Nghiên cứu của Nguyễn Hoài Nga, Trần Văn Thuấn, Bùi Diệu và CS (2011, $\mathrm{n}=11.555)$ [2] cho thấy, tỷ lệ bệnh nhân trên 40 tuổi mắc ung thư phổi là $94,6 \%$. Các nghiên cứu trên thế giới đều ghi nhận rằng, nam giới có tỷ lệ mắc UTP cao hơn nữ giới. Tỷ lệ nam/nữ dao động từ 2,5 - 4/1. Nghiên cứu của chúng tôi lại cho thây số bệnh nhân nam nhiêu hơn nữ nhưng không quá chênh lệch. Điều này có thể giải thích do nữ giới có tỷ lệ đột biến EGFR cao hơn ở nam giới, đặc biệt là nhóm nữ không hút thuốc, phổ biến tại các nước phương Đông trong đó có Việt Nam [3]. Chính vì vậy, tỷ lệ bệnh nhân nữ được điều trị bằng thuốc nhắm trúng đích trong nghiên cứu này cao.

Chỉ số toàn trạng là yếu tố rất quan trọng trong viêc lựa chọn phương pháp điêu trị cho bệnh nhẩn ung thư phổi khổng tế bào nhỏ cũng như đánh giá tình trạng sức khỏe của bệnh nhân tốt lên hay xấu đi trong quá trình điều trị.

Trong nghiên cứu của chúng tôi, nhóm bênh nhân có chỉ số $P S=0$ và $P S=1$ chiếm $81,2 \%$.

Biểu hiện lâm sàng của ung thư phổi rất đa dạng. Các triệu chứng giai đoạn đầu của ung thư phổi rất nghèo nàn, ít đặc hiệu rất khó phân biệt với viêm phế quản, lao phổi và được điều trị không đúng hướng trong một thời gian dài cho đến khi triệu chứng nặng hớn mới chú ý đến chẩn đoán theo hướng ung thư phổi. Do đó bệnh nhân thường đi khám khi đã có triệu chứng, trong nghiên cứu của chúng tôi lý do đến khám phổ biến nhất là đau ngực chiếm $33,8 \%$, tiếp theo là ho kéo dài $16,9 \%$ và ho ra máu chiếm $11,8 \%$. Trong nghiên cứu của chúng tôi tỷ lệ khối u xếp loại T2 và T3 chiếm tỷ lệ cao nhất 91,5\%, kết quả của chúng tôi cao hơn với kết quả của một số tác giả khác với tỷ lệ gặp nhiều nhất trong nhóm bệnh nhân có kích thước khối u T2, T3 là $64,8 \%$ và $66,1 \%$. Khi phân tích các đăc điểm di căn cho thấy: di căn phổi đối bên gặp nhiều nhất với 21 bệnh nhân chiếm 35,6\%, các vị trí thường gặp tiếp theo là di căn xương với tỷ lệ $35,6 \%$ tiếp đến là di căn màng phổi chiếm $20,3 \%$. Kết quả này tương đương với tỷ lệ gặp di căn của một số nghiên cứu của Lê Thu Hà với tỷ lệ di căn phổi, màng phổi và xương vẫn là phổ biến nhất với các tỷ lể lần lượt là $49,4 \%, 46,5 \%$ và 43\% [4]. Các vị trí di căn ít gặp hơn trong nghiên cứu này gồm có não $(18,5 \%)$, gan $(13,0 \%)$, thượng thận $(16,7 \%)$. Trong nghiên cứu của chúng tôi có 25 bệnh nhân mang đột biến gen thường gặp là exon $19 \mathrm{DEL}$ chiếm tỷ lệ $42,4 \%$ và exon 21 L858R chiếm tỷ lệ $32,2 \%$. không có trường hợp bệnh nhân nào mang đột biến gen trên cả 2 exon 19 và 21 . Kết quả này tương tự như kết quả của nhiều nghiên cứu ở Việt Nam và trên thế giới. Ở Việt Nam, nghiên cứu của Lê Thu Hà cho thấy tỷ lệ đột biến gen của exon 19 là 67,1\% [4]. Theo nghiên cứu Pioneer tỷ lệ đột biến gen EGFR tại Việt Nam là $64,2 \%$ trong đó $47,8 \%$ là đột biến tại exon 19 và $45,1 \%$ có đôt biến tai exon 21 , còn lại là các đột biến hiếm gặp khác. Việc đánh giá điều trị dựa vào theo dỗi lâm sàng, chẩn đoán hình ảnh, xét nghiệm cận lâm sàng và cách đánh giá dựa theo tiêu chuẩn Recist 1.1. Cũng giống như việc đánh giá điều trị hóa chất với ung thư phổi, đánh giá hiệu quả điều trị Afatinib được đánh giá thông qua tỷ số kiểm soát bệnh (tỷ lệ đáp ứng + tỷ lệ bệnh giữ nguyên). Trong nghiển cứu của chúng tôi có 59 bệnh nhân, thì tỷ lệ đáp ứng một phần chiếm tỷ lệ cao nhất với 33 bệnh nhân $(55,9 \%)$, 8 bệnh nhần bệnh giữ nguyên $(13,6 \%), 12$ bênh nhân bệnh đáp ứng hoàn toàn $(20,3 \%), 6$ bệnh nhân bệnh tiến triển (10,2\%). Qua đó giúp xác định:

- Tỷ lệ bệnh đáp ứng với điều trị (bệnh đáp ứng hoàn toàn + đáp ứng một phần) là $76,2 \%$.

- Tỷ lệ kiểm soát bệnh (đáp ứng hoàn toàn + đáp ứng một phần + bệnh giữ nguyên) là 89,9\%. 
Kết quả nghiên cứu của chúng tôi tương đương với nghiên cứu LUXLUNG 3, LUXLUNG 6 và LUXLUNG 7 với tỷ lệ đáp ứng (ORR) và tỷ lệ kiểm soát bệnh (DCR) lần lượt là $56 \%$ và $90 \%$ [5]; $67 \%$ và $93 \%[6] ; 70 \%$ và $91,3 \%$. Kết quả này cũng tương đồng với một số nghiên cứu ngoài đời thực về tỷ lệ đáp ứng (ORR) như nghiên cứu của tác giả Liang và CS (2018) là 69,5\% [7]; Đánh giá tỷ lệ đáp ứng theo vị trí di căn, trong nghiên cứu của chúng tôi, tỷ lệ đáp ứng đối với tổn thương phổi đối bên là $65,3 \%$, đối với tổn thương não là $80 \%$ đối với tổn thương thượng thận là $66,7 \%$ và tổn thương gan là $71,4 \%$. Qua đẩy chúng ta có thể thấy được bức tranh toàn cảnh về đáp ứng điều trị của nhóm bệnh nhân trong nghiên cứu ung thư phổi biểu mô tuyến, giai đoạn IV, có đột biến gen EGFR với TKIs thế hệ 2 Afatinib.

Kết quả nghiên cứu của chúng tôi cho tỷ lệ đáp ứng của nhóm bệnh nhân có đột biến gen EGFR thường gặp đạt 79,5\%. Trong đó nhóm bệnh nhân có vị trí đột biến ở exon 19 DEL có tỷ lệ đáp ứng cao hơn nhóm bệnh nhân có vị trí đột biến ở exon 21 L858R (88\% so với 68,4\%), tuy nhiên sự khác biệt này không có ý nghĩa thống kê với $p=0,406$. Kết quả này cũng tương đương với nghiên cứu LUXLUNG 3,6,7 với tỷ lệ đáp ứng lần lượt $56 \%, 67 \%, 70 \%$. Nghiên cứu của chúng tôi cho kết quả tương tự như tác giả Lê Thu Hà (2017) [4] khi tỷ lệ đáp ứng với bệnh nhân có đột biến gen exon 19 cao hơn đột biến gen exon 21 (42,6\% so với $29 \%)$ nhưng sự khác biệt không có y nghĩa thống kê với $p=0,157$ [8]. Trên thế giới kết quả nghiên cứu LUXLUNG 7 về tỷ lệ đáp ứng ở nhóm bệnh nhân có vị trí đột biến exon 19 DEL và exon 21 L858R cũng cho kết quả tương tự với kết quả lần lượt là 75\% và 69\%.

Trong nghiên cứu của chúng tôi có 15 bệnh nhân đột biến gen EGFR hiếm gặp. Trong đó số bệnh nhân có đáp ứng là 10 bệnh nhân chiếm tỷ lệ $66,7 \%$. Kết quả này trong nghiên cứu của chúng tôi tương đương với nghiên cứu của Yang và CS (2015) [6] khi phân tích gộp nhóm bệnh nhân có đột biến EGFR hiếm gặp từ các nghiên cứu LUXLUNG 2,3 và 6 với tỷ lệ đáp ứng là $71,1 \%$, xét riêng đáp ứng từng vị trí đột biến như sau: exon 18 G719X (78\%); exon 21 L816Q (56\%); exon 20 S768I (100\%). Afatinib có hiệu quả trên các bệnh nhân đột biến hiếm đặc biệt các đột biến G719X, L861Q, và S768I được xem là ít đáp ứng với TKIs thế hệ 1 [9]. Trước đây, ung thư phối không tế bào nhỏ giai đoạn di căn là khó khăn do hiệu quả đáp ứng điều trị hóa chất còn hạn chế và các tác dụng phụ nhiều.
Ngày nay, các thuốc điều trị nhắm trúng đích TKIs đã giúp giải quyết khá tốt các khó khăn trên: hiệu quả điều trị tăng cao hơn, các tác dụng phụ nhẹ nhàng hơn. Nhìn chung khi phân tích các tác dụng không mong muốn của Afatinib thường gặp nhất là các độc tính đường tiêu hóa, trên da, niêm mac và do thuốc thải trừ qua gan, thận nên cũng cần lưu ý các tác dụng phụ nên 2 cơ quan này. Trong nghiên cứu của chúng tôi, cho thấy tác dụng không mong muốn hay gặp nhất khi điều trị Afatinib là tiêu chảy chiếm tỷ lệ $88,9 \%$ ở tất cả các độ, trong đó độ 3 chiếm $11,1 \%$, không gặp độ 4 . Ban da dạng mụn chiếm tỳ lệ $87,1 \%$ trong đó độ 3 chiếm 9,3\%, không gặp độ 4. Tác dụng không mong muốn khác như khô da, mệt mỏi, viêm miệng và viêm kẽ móng chiếm tỷ lệ lần lượt là: $31,5 \%, 38,8 \%, 27,8 \%$, $68,5 \%$ và $48,1 \%$. Các tác dụng không mong muốn hầu hết ở mức độ nhẹ, độ III và IV là rất ít gặp. Như vậy, nhìn chung điều trị bằng Afatinib cho bệnh nhân ung thư phổi không tế bào nhỏ là an toàn, ít tác dụng phụ.

\section{KẾT LUÂNN}

Tỷ lệ đáp ứng chung toàn bộ là $76,2 \%$; bệnh giữ nguyên là 13,6\%; tỷ lệ kiểm soát bênh đạt $89,8 \%$.

Tác dụng không mong muốn thường gặp nhất là tiểu chảy $(88,9 \%)$ và ban mụn trên da $(87,1 \%)$ chủ yếu ở độ 1 và độ 2 . Không có bệnh nhân nào tử vong do tác dụng phụ không mong muốn.

\section{TÀI LIÊU THAM KHẢO}

1. Ferlay J., Colombet M., Soerjomataram I. và công sư.' (2019). Estimating the global cancer incidence and mortality in 2018: GLOBOCAN sources and methods. Int J Cancer, 144(8), 1941-1953.

2. Nguyển Hoài Nga, Bùi Diệu, Trân Văn Thuấn, và CS Một số đặc điểm dịch tế, lâm sàng, cận lâm sàng ung thư phổi nguyên phát chẩn đoán điêuu trị tại bệnh viện $K$ trong 10 năm từ 2001 đến 2010,. Tap chí Ung thư hoc Việt Nam số 2, 7.

3. Mai Trọng Khoa, Ngô Thùy Trang, Nguyễn Thị Lan Anh và CS (2016), Nghiên cứu tiến cứu, dịch tể học phân tử, đánh giá tình trạng đột biến gen EGFR ở các bệnh nhân Việt Nam mắc ung thư phổi dạng biểu mổ tuyến, giai đoạn tiến triển. Tạp chí Ung thư học Việt Nam, 2/2016, 30-36.

4. Lê Thu Hà, Trân Văn Thuấn (2016). Đáp ứng thuốc erlotinib trong điều trị bệnh nhân ung thư phổi không tế bào nhỏ giai đoạn muộn, Tạp chí Y hoc thực hành, 993, 53-55.

5. Kato T., Yoshioka H., Okamoto I. và cộng sự. (2015). Afatinib versus cisplatin plus pemetrexéd in Japanese patients with advanced non-small cell lung cancer harboring activating EGFR mutations: Subgroup analysis of LUX-Lung 3. Cancer Sci, 106(9), 1202-1211.

6. Wu Y.-L., Zhou C., Hu C.-P. và cộng sự. (2014). Afatinib versus cisplatin plus gemcitabine for first- 
line treatment of Asian patients with advanced nonsmall-cell lung cancer harbouring EGFR mutations (LUX-Lung 6): an open-label, randomised phase 3 trial. Lancet Oncol, 15(2), 213-222.

7. Liang S.-K., Lee M.-R., Liao W.-Y. và cộng sứ. (2018). Prognostic factors of afatinib as a firstline therapy for advanced EGFR mutation-positive lung adenocarcinoma: a real-world, large cohort study. Oncotarget, 9(34), 23749-23760.
8. Lê Thu Hà Đánh giá hiệu quả cửa thuốc Erlotinib trong điều trị ung thư phổi biểu mô tuyến giai đoan muôn Nghiên cứu sinh tiến sĩ năm 2017, đại học Y Hà Nội .

9. Yang J.C.-H., Sequist L.V., Geater S.L. và cộng sự. (2015). Clinical activity of afatinib in patients with advanced non-small-cell lung cancer harbouring uncommon EGFR mutations: a combined post-hoc analysis of LUX-Lung 2, LUX-Lung 3, and LUX-Lung 6. Lancet Oncol, 16(7), 830-838.

\title{
XÁC ĐINNH TRUNG Vİ CỦA CÁC BIOMARKER TRONG TÂM SOÁT LÊCH BộI QUÝ 1 THAI KÌ TẠI BÊ̂NH VIỆN ĐẠI HỌC Y DƯỢC TP. HỒ CHÍ MINH
}

\author{
Nguyễn Thị Hương Xuân*, Trần Nhật Thăng**
}

\section{TÓM TẮT}

Đăt vấn đề: Thay đổi nồng đô PAPP-A và free beta-hCG (fß-hCG) trong máu me được chứng minh là có liên quan đến nguy cơ mắc hội chứng Down ở thai nhi. Một số nghiên cứu cho thấy trung vị hai chất này thay đổi theo chủng tôc và không thể giải thích đước bằng hiệu chỉnh cân nặng mẹ. Mổi dân tộc nên có giá trị tham chiếu riêng cho dân số mình. Mục tiêu: Xác định giá trị trung vị của PAPP-A và $f \beta-h C G$ của dân số đại học Y Dược Tp. Hồ Chí Minh (ĐHYD). Phương pháp: Nghiên cứu báo cáo loạt ca hồi và tiến cứu 2873 thai phu đến khám tại đởn vị chẩn đoán trước sanh bệnh viển ĐHYD TP. Hồ Chí Minh được sàng lọc quí 1 thai kì bằng combined test. Kết quả: Trung vị dư đoán: PAPP-A=214,3 - 5,384 x (ngày tuổi thai) + $0,03415 \times$ (ngày tuổi thai) ${ }^{2} \mathrm{r}=0,9677 ; \mathrm{f} \beta-\mathrm{hCG}=10^{\wedge}$ $(-0,06799 \times$ (ngày tuổi thai) $+7,581) r=0,991 ;$ Mô hình điều MoM theo cân nặng mẹ: PAPP-A MoM hiệu chỉnh $=0,3628^{*} \operatorname{EXP}\left(0,01705^{*}\right.$ cân nặng $\left.\mathrm{Kg}\right)$; $\mathrm{f} \beta$-hCGG MoM hiệu chỉnh $=1,665^{*} \operatorname{EXP}(-0,005857 *$ cân nặng $\mathrm{Kg}$ ); Trung vị MoM PAPP-A khi sử dụng mô hình đặc trưng cho dân số ĐHYD là 0,896 khác biệt với trung vị MOM PAPP-A khi sử dung mô hình của FMF là 1,064 (95\% CI, $p<0.05)$. Trung vị MoM $f \beta-h C G$ khi sử dụng mô hình đặc trưng cho dân số ĐHYD là 1,221 khác biệt với trung vị MoM fß-hCG khi sử dụng mô hình của FMF là $1,433(95 \% C I, p<0.05)$. Sơ sánh hai mô hình: Tî lệ dương tính của test sàng lọc khi áp dụng MoM- FMF là 7,62\%.Tỉ lệ dương tính của test sàng lọc khi áp dụng MoM-ĐHYD là 8,8\%. Khi áp dung MoMĐHYD: Tí lệ phát hiện là $100 \%$. Tỉ lệ tiên đoán dương: 7,11\%; Tỉ lệ dương giả: 8,18\%. Kết luận: Mỗi chủng tộc nên áp dụng giá trị trung vị PAPP-A và $\mathrm{f} \beta$-hCG riềng của dân số mình cho sàng lọc lệch bội ba tháng đâu thai kì bằng combined test.

Tư khóa: Chủng tôc, hôi chứng Down, sàng loc trước sanh, ba tháng đầu, PAPP-A, Free beta-hCG

\section{*Đại học Y Dước TP.HCM}

Chiu trách nhiếm chính: Nguyễn Thị Hương Xuân

Email: huongxuannguyen0402@ump.edu.vn

Ngày nhận bài: 12.8 .2021

Ngày phản biện khoa học: 6.10.2021

Ngày duyệt bài: 15.10.2021

\section{SUMMARY \\ DETERMINATION OF THE MEDIAN LEVELS OF SERUM BIOMARKERS IN THE FIRST TRIMESTER SCREENING PROGRAM IN PREGNAN WOMEN OF UNIVERSITY MEDICAL CENTER HOSPITAL}

Background: Low serum concentrations of pregnancy-associated plasma protein-A (PAPP-A) and increased levels of free $\beta$-human chorionic gonadotropin (f $\beta$-hCG) at $11-13$ weeks 6 days of pregnancy are associated with an increased risk of fetal Down syndrome (trisomy 21). Several studies indicated that the serum concentrations of PAPP-A and $\mathrm{f} \beta$-hCG present during pregnancy were different between ethnicities and the difference could not be compensated by weight correction. All ethnic groups should have their own reference ranges of these 2 serum biomarkers. Objective: to determine median level for serum levels of PAPP-A and $A \beta-h C G$ in the UMC population. Methods: The study reported a series of retrospective and prospective cases of 2873 pregnant women who visited the prenatal diagnosis unit of the University of Medicine and Pharmacy Hospital in Ho Chi Minh City was screened for the first trimester of pregnancy by combined test. Results: UMC reference ranges of PAPP-A and $f \beta-h C G$ were established by gestational age (77-97 days). The equation of best fit for PAPP-A was: predicted median PAPP-A level $=214,3-5,384 \times$ (gestational age in days) $+0,03415 \times$ (gestational age in days) ${ }^{2} ; r=0,9677$. The equation of best fit for $f \beta-h C G$ was: predicted median $\mathrm{f} \beta$-hCG level $=10^{\wedge}(-0,06799 \times$ (gestational age in days) $+7,581) ; r=0,991$. Weight-corrected models were also derived for each biomarker. PAPP-A MoM corrected $=0,3628 * \operatorname{EXP}\left(0,01705^{*}\right.$ weight $\left.\mathrm{Kg}\right) ; \mathrm{f} \beta$-hCG MoM corrected $=1,665 * \operatorname{EXP}(-0,005857 *$ weight $\mathrm{Kg})$. The median MoM PAPP-A when using the UMC-specific model was 0,896 , and the median MoM PAPP-A when using the FMF model was 1,064 (95\% CI, $p<0.05)$. The median MoM f $\beta$-hCG when using the UMC-specific model was 1,221 , and the median MoM $\mathrm{f} \beta$-hCG when using the FMF model was 1,433 (95\% CI, $p<0,05)$. The UMC-specific reference ranges gave higher positive screening rates than the FMF model, even 